\title{
Realism and Political Normativity
}

\section{Matt Sleat ${ }^{1}$ (D)}

Accepted: 20 September 2021 /Published online: 28 October 2021

(c) The Author(s) 2021

\begin{abstract}
A prevailing understanding of realism, chiefly among its critics, casts realists as those who seek a 'distinctively political normativity', where this is interpreted as meaning nonmoral in kind. Moralists, on this account, are those who reject this and believe that political normativity remains moral. Critics have then focused much of their attention on demonstrating that the search for a nonmoral political normativity is doomed to fail which, if right, would then seem to fatally undermine the realist endeavour. This paper makes the case that casting the difference between realism and moralism in these terms is a mistake, one which overlooks the substantial body of realist work which is clear that it has no such aspirations to develop a nonmoral political normativity. The hope is that in drawing attention to this mistake a line can be drawn under these unhelpful debates, and we can move on to more fruitful constructive and critical discussions between realists and their critics.
\end{abstract}

Keywords Realism $\cdot$ Moralism $\cdot$ Political normativity

Much hay has been made in recent years of political normativity. This issue has come to be seen as central to and characteristic of the 'new' political realism that has emerged within the last decade or so. On a prevailing account, realists are those who seek a 'distinctively political normativity', where this is interpreted as meaning nonmoral in kind, and critics of realism have focused much of their attention on attempting to demonstrate that such an ambition is doomed to fail. If this is right as a broad description of where much of the debate between realism and its critics has ended up, then it would seem, to put it this way, that the possibility of nonmoral political normativity is the hill on which realists must be willing to die. For if it turns out that a nonmoral political normativity is impossible or incoherent then political realism itself seems fatally undermined.

This paper makes the case that casting the debate between realists and moralists in terms of the prospects of a nonmoral political normativity is a mistake. It is a mistake which has largely been the result of a misinterpretation of realism's ambitions by its critics, and in

Matt Sleat

m.sleat@sheffield.ac.uk

1 Department of Politics and International Relations, University of Sheffield, Sheffield, USA 
the first section we shall examine Jonathan Leader Maynard and Alex Worsnip's 'Is There a Distinctively Political Normativity?' (2018), which explicitly casts the realism/moralism debate in these terms, to demonstrate such misunderstandings at work. ${ }^{1}$ To be fair to such critics, and as we shall see in the second section, there is a strand of realist thought which does seek a nonmoral political normativity and so has sought to do battle on those grounds. But that represents a very particular understanding which does not characterise realism per se and, very importantly, it is not the strand critics target in their discussions. More 'mainstream' realism, so to speak, is very clear that the commitment is to a notion of political theory that gives politics 'greater' autonomy from morality, an ambition which (however expressed and understood by individual realists) does not depend on demarcating moral and nonmoral political normativities. Indeed, realists have often been explicit that such a demarcation is not part of their project. In the final section, we shall revisit Bernard Williams' realist theory, often taken to be the main influence in this realist quest to identify a nonmoral political normativity, to show that the origins of the realist/moralist distinction turned not on the demarcation of different normativities but on how political theory understands the relationship between morality and political practice. Though Williams' work has been hugely influential, realism is a 'distinctive family' of approaches related by variations on recognisably realist claims about the distinctiveness or autonomy of politics. Critics therefore ought to engage with particular realist arguments rather than force realism into a false unity around a commitment that very few actually hold. As such, the debates around nonmoral political normativity have been a largely unnecessary and unhelpful detour which has detracted attention, both constructive and critical, from potentially more fruitful debates.

\section{Nonmoral Political Normativity}

According to Leader Maynard and Worsnip, and in one of the most recent and fully-developed critiques of realism, realists contend 'that political normativity is its own distinctive kind of normativity, independent of moral normativity. A key source for this view is found in the political writings of Bernard Williams, subsequently developed by several others' (2018, p. 757). Whereas moralists take political normativity to be a form of moral normativity, realists believe, Leader Maynard and Worsnip claim, that political normativity is not a kind of moral normativity at all, but is an independent, distinctive, nonmoral normativity in its own right (2018, p. 759). And the purpose of their paper is to demonstrate that the attempt to place a distinctively political, nonmoral normativity at the core of that [realist] agenda - at least on the basis of the arguments thus far offered-is a mistake' (2018, p. 757).

Having framed the debate between realists and moralists in these terms, Leader Maynard and Worsnip admit frustration that they have been unable to find clear arguments from realists in favour a distinctive and nonmoral political normativity (2018, pp. 759, 786). They do nevertheless identify two claims which they take as (unsuccessful) realist attempts at a demarcation of morality from politics with the purpose of underpinning that distinctive nonmoral political normativity. The first is that realists sometimes 'implicitly characterise

\footnotetext{
1 A similar argument to Leader Maynard and Worsnip's can be found elsewhere. See, for example, Erman and Möller (2015, Forthcoming); Miller (2016), Estlund (2017).
} 
the moral domain as including only the principles that govern private interactions between individuals'(2018, p. 760). Politics is therefore nonmoral because, by definition, it deals with the interactions of political rather than private agents. The second and related claim is that there are principles, concepts, considerations, values, and actors, which are distinctive of the political domain, and political normativity is nonmoral because it deals specifically with those principles, concepts, etc. (2018, pp. 760-63).

Given that the aim of these passages is to evidence how realists themselves understand or frame their disagreement with moralists in terms of nonmoral and moral political normativities, surprisingly few references are provided to corroborate this claim. There are five references to only four sources, ${ }^{2}$ three of which were published in or before $2010 .^{3}$ That might be sufficient if these sources did indeed show that this is how realists (not just these particular realists) contrast their approach to moralism. Unfortunately, they do not corroborate Leader Maynard and Worsnip's claim insofar as it is hard to see that the authors are attempting to make the sort of demarcation between a nonmoral and a moral political normativity at all.

Mark Philp's paper 'What is to be Done? Political Theory and Political Realism' (2010) appears twice in these references. The argument of Philp's paper is that liberal ideal theory is a poor guide for the evaluation of political conduct because it tends to focus more on identifying and analysing the scope and implications of values and principles, and we need to attend also (not instead) to the practicalities of political action and choice. He stresses that amending our focus in that way can still underpin a normative theory of politics. But at no point does he seek to make a distinction between a nonmoral political and a moral normativity. Indeed, if we attend to Philp's monograph on this topic published three years before the paper, we find an explicit endorsement at the beginning of the book of the thought that

... the relationship between moral philosophy and politics is not deductive, ... many of the abstract values found in moral philosophy and much liberal political theory are profoundly inflected by their interpretation, implementation, and realisation in political action. This view accords the political process a substantial degree of autonomy and an identity and character of its own. Politics, and political conduct in this view, needs to be understood largely, although not entirely, on its own terms, and those terms concern the political virtues and qualities of the actors involved (Philp, 2007, p. 4 - emphasis added).

Evaluating political conduct requires identifying the standards that are intrinsic and internal to it [politics], together with some sense of the conditions under which those standards may come to have, or may lack, ethical weight' (Philp, 2007, p. 2-emphasis added). Such nuanced pronouncements seem hard to square with Leader Maynard and Worsnip's

\footnotetext{
${ }^{2}$ Excluding the passing reference to Hans J. Morgenthau who, as an IR realist, lies somewhat beyond the scope of their paper and this.

32010 being relevant here as this was when the special issue of the European Journal of Political Theory was published which did much to inaugurate the revival of interest in realist thought. Indeed, two of the referenced pieces - those by Newey and Philp - are from that special issue. Similarly, in their contribution to this special issue, Erman and Möller also cite four papers from that EJPT issue (including those by Philp and Newey) as evidence of the realist commitment to a nonmoral political normativity (Forthcoming, p. 2). It is unfortunate that both that paper and the one under discussion here pays relatively little attention to the substantial body of realist work published after 2010 given, as we shall shortly see, much of this is explicit and clear that the development of a nonmoral political normativity is not an ambition.
} 
interpretation of Philp as seeking to show that as 'private morality is unquestionably a part of morality, then, political normativity cannot be a part of morality' (2018, p. 777).

Glen Newey's 'Two Dogmas of Liberalism' is also referenced in support of their account of how realists understand their project. It is true that part of Newey's concern in that paper is to resist the thought that 'the norms which justify an individual in acting a certain way carry over to the sphere of collective action' (2010, p. 450). But that is part of a broader attack specifically on what he calls 'Kantian reductivism' which (he believed) attempts to reduce political normativity to morality and in particular retain the notion that morality trumps reasons of all other kinds at either the individual or collective level. What the argument does not and is not supposed to show is that because morality applies to the private domain so political normativity must be nonmoral. At the most it would show that political normativity cannot be moral in that Kantian reductive sense. Indeed, Newey is clear that even if he is right about this that would not demand 'a wholesale abandonment of Kantianism, in attempting to construct a serviceable notion of political normativity' (2010, p. 450). In fact, the more realistic ('holistic') view that he goes on to develop in the second half of the paper is explicitly Kantian insofar as 'One has to regard oneself as free in relation to acts of authorisation as a condition of being incorporated with others' (2010, p. 458). Political holism rejects 'strong foundationalism, as a set of (say, moral) norms, resting on intuitively compelling premises, which determine basic political and civil rights and obligations, the design of key institutions and procedures, and the distribution of basic goods' (2010, p. 459). This is perfectly consistent with the project of his monograph, After Politics, where he is clear that he is criticising the methodological assumption of the 'sovereignty of morality' which says 'that moral considerations take precedence over others, and therefore the task of political philosophy is to attempt the project of political design guided by what theory takes to be its fundamental moral commitment or value - justice, autonomy, rights, equality, and so on' (2001, pp. 106-07). Does rejecting the strong foundational claims of moral norms equate with a nonmoral form of political normativity? Newey does not say. Even if it does, Newey does not think his political holism follows from the rejection of Kantian reductivism (it is explicitly 'asserted' in the place of the two dogmas of liberalism he rejects) (2010, p. 459). One thus suspects distinguishing between a moral and a nonmoral political normativity was not quite his concern as Leader Maynard and Worsnip suggest. ${ }^{4}$

\footnotetext{
${ }^{4}$ The final reference Leader Maynard and Worsnip provide is to a very brief piece by Rob Jubb and Enzo Rossi (2015) As we shall see in the following section, this piece and Rossi's work more generally can legitimately be understood in terms of attempting to demarcate a nonmoral political normativity. Hence we can leave discussion of it until then. However, it is worth saying that it is far from clear that Leader Maynard and Worsnip are right to present Jubb and Rossi's argument against moralism as turning at all on corporateto-individual-reductivism. The only passage on the page they reference which could potentially be seen as relevant here would seem to be the following: 'Indeed, in a sense realists seem to be less cynical than moralists. They believe our politics, if far from perfect, is not straightforwardly tyrannical, and hope to use its combination of coercion and consent to generate norms to govern it. Moralists on the other hand demand that politics accord with their private moral views and tend to see it as an arena of brute force when it does not, denying that the act of providing an order itself has a normativity' (457 - emphasis added). If this is the passage they are referring to then it is hard to read this as regarding corporate-to-individual-reductivism because 'private' here clearly does not refer to relations between private individuals but something like personally-held views of what should be done politically, a reading that Leader Maynard and Worsnip also seem to accept (footnote 42, p. 771). As such, though we can say that Jubb and Rossi are advocating nonmoral political normativity it is not for the reasons Leader Maynard and Worsnip ascribe to them.
} 
The second but related claim Leader Maynard and Worsnip ascribe to realists in their attempt to render substantive the distinction between moral and nonmoral political normativity is that the latter must deal specifically with the principles, concepts, considerations, values, and actors which are distinctive of the political domain. This is indeed a staple realist claim, and a passage from Williams' 'From Freedom to Liberty: The Construction of a Political Value' is used to demonstrate this (political philosophy, he says, 'must use distinctively political concepts, such as power, and its normative relative, legitimation' (2005, p. 77)). Does Williams intend that claim about the specificity of the political domain to ground a nonmoral political normativity? It is certainly true that Williams wanted to explore how one could construct freedom as a political value in that paper. But he is careful as to how he presents the task.

In the sense that concerns these discussions, freedom is a political value ... I am going to suggest that this point itself, when it is properly understood, has a very significant effect on the kind of construction we should be trying to achieve. In particular, we must take seriously the point that because it is a political value, the most important disagreements that surround it are political disagreements. What kinds or registers of politics are involved, what the relevant understandings of politics will be, will depend on which disagreements are at issue - those within our own societies, for instance, or those with other societies. But our overall construction of freedom as a political value must allow for the fact that it is a political value to be central and intelligible (2005, pp. 76-7).

Note two things: Firstly, Williams says nothing here about trying to demarcate a political from a moral normativity, let alone a nonmoral political from a moral political normativity. Secondly, he is clear that he is trying to bring to the fore the significance of what it means to think of freedom as a political value. There is no implication that this can or that we should even want this to exhaust all that can be said of freedom as a value. Indeed, it is consistent with his general genealogical approach that we are not going to be able to offer even a coherent understanding of freedom which does not take into account its ethical developments and dimensions throughout history. It is far from clear, therefore, that citing this passage or paper is sufficient to show that Williams was engaged in an attempt to demarcate a nonmoral political normativity from morality. ${ }^{5}$

Whatever Philp, Newey and Williams were trying to do in the passages Leader Maynard and Worsnip cite, it was not what they claim they were trying to do. That they found it difficult to identify clear accounts of the terms of a dispute between those who think political normativity is nonmoral on one side and those who think it is moral on the other is probably because that does not capture the nature of the disagreement in the first place. Like explorers who find that the topography of a region bears little resemblance to their map and blame the mountains and rivers for being in the wrong place, the difficulty with their enterprise is that they start with a mischaracterisation of realism and then express bafflement that they cannot find a precise statement by any realists of a position that they do not hold.

\footnotetext{
5 A greater appreciation of Williams' broader thought gives us good reason to suspect that he would not be engaged in such a project of demarcating normativities at all, a point we shall return to in the final section.
} 


\section{Distinctively Political Normativity as the Irreducibility of Politics to Morality}

Though Leader Maynard and Worsnip set themselves the question 'is there a distinctively political normativity?', they interpret 'distinctively' to mean independent such that a political normativity must be nonmoral to qualify and then find that realism falls short. Clearly, and by definition, it is a sufficient condition for a political normativity to be distinctive from morality that it be nonmoral. But it is not a necessary condition and the notion of distinctiveness need not imply that. Things can be distinctive but still in various ways similar, and in that sense there is no requirement of full separateness. We might say 'That is a distinctively Wagnerian opera' without meaning that it has no comparable characteristics with an opera by Verdi or Puccini. In the same way, political normativity can be distinctive without being nonmoral. That is an obvious point. Hence it raises the question why critics have assumed that talk of political normativity indicates a commitment to nonmoral political normativity. Leader Maynard and Worsnip are not alone in thinking that this is a realist commitment. Where has this idea come from?

The first thing to say is that there is an important sense in which they are right: it is true that there is one strand of realist thought which does seek to carve out a distinctively nonmoral political normativity, just not the strand that is the target of most criticisms. In our overview of the state of the realist debate published in 2014, Enzo Rossi and myself distinguish between two ways in which a realist theory can still be normative depending on how you understand the relationship between politics and morality. The stronger version demands full autonomy from morality, claiming 'that it is possible to derive normative political judgments from specifically political values - a position resting on the view that not all values are moral values, plus the more controversial claim that such political values can and should guide politics, whereas moral values are ill-suited to that task' (Rossi and Sleat, 2014, p. 690). ${ }^{6}$ This stronger version is more inspired by the work of Raymond Geuss than Williams (recall Leader Maynard and Worsnip claim that the latter was the 'key source' of the aspiration for a distinctive nonmoral political normativity), is closely aligned to critical theory, and now strongly associated with the 'radical' realists. ${ }^{7}$ A prominent member of these radicals is Rossi himself who has explicitly equated moralism with the view that 'normative standards that appropriately regulate personal interactions should also regulate political life' and realism with a normativity whose source is nonmoral (Rossi, 2019). ${ }^{8}$ But while this represents a rather energetic strand of contemporary realist work it is nevertheless both somewhat idiosyncratic and certainly unrepresentative of realism as a whole. Critics have a target, then, if they wish to critique a realism which is committed to nonmoral political normativity, but it is a quite specific one and would need to be represented as such in a way that it currently is not. ${ }^{9}$

This stronger version of realism is contrasted by Rossi and myself with a weaker variant:

\footnotetext{
${ }^{6}$ As they go on to note: 'Whether and how either or both components of that claim can be sustained is an issue high on the agenda of realists and of their critics. The controversy largely turns on whether moral normativity is eliminable from political philosophy'.

7 See, for example, Geuss, 2008, 2014.

8 See also Jubb and Rossi (2015), Prinz (2016), Prinz and Rossi (2017), Raekstad (2018).

9 For instance, in their contribution to this special issue, Erman and Möller cite Rossi's work, including the piece discussed above co-authored with Jubb, as evidence of a general realist commitment to politics as 'an autonomous, independent domain with its own evaluative standards' (Erman and Möller, Forthcoming, p. 2).
} 
there is a place for morality in politics but [it] seeks, in Williams' words to explicate 'an approach which gives greater autonomy to distinctively political thought'. On this view, there is not such a stark contrast between politics and morality, and indeed morality may have a role to play in providing a source of political normativity, yet it remains important to appreciate the manner in which politics remains a distinct sphere of human activity, with its own concerns, pressures, ends and constraints which cannot be reduced to ethics (nor law, economics, religion, etc.) (2014, p. 690).

Advocates of the weaker thesis more often talk in terms of politics being 'distinct' from morality, or of it being 'irreducible' to morality. They might still also emphasise the 'autonomy' of politics, though they do not mean by that the sort of full or complete autonomy from morality we find with the stronger version of the thesis. As Alison McQueen points out, autonomy in this context often just means something like politics not being reducible to other fields or domains (2018, p. 246). ${ }^{10}$ To take some illustrative examples from the realist literature:

While this [claim that politics is a distinct sphere of human activity] can often be somewhat overstated as demonstrating the 'autonomy of the political' from all other domains, morality, economics, law, etc., such that politics has its own completely unique internal logic, the claim is better stated that there must be some space within a theoretical account of politics that can recognise the distinctiveness of the political sphere, that it does have its own character, purposes and means, while also acknowledging that it sits in a series of complex relationships with other human activities. What realism rejects is any understanding of politics in which the distinctiveness of politics is overlooked (Sleat, 2014b, p. 32). ${ }^{11}$

[R]ealists are committed to the idea that we should not reduce political philosophy (or politics) to moral philosophy (or morality) because they stress the "distinctiveness and autonomy of the political from other spheres" (Hall, 2017, p. 284). ${ }^{12}$

[Realism is] a family of approaches to the study, practice, and normative evaluation of politics that (a) affirms the autonomy (or, more minimally, the distinctiveness) of politics; (b) takes disagreement, conflict, and power to be ineradicable and constitutive features of politics; (c) rejects as 'utopian' or 'moralist' those approaches, practices, and evaluations which seem to deny these facts; and (d) prioritizes political order and stability over justice (or, more minimally, rejects the absolute priority of justice over other political values) (McQueen, 2017, p. 297). ${ }^{13}$

\footnotetext{
${ }^{10}$ See also Sleat (2018, pp. 6, 7). The use of terms such as 'external' may also have been unhelpful in this regard (a term Williams did not use to discuss the relationship between politics and morality, incidentally), and was sometimes employed, especially in early realist work, so as to distinguish political realism as a form of theorising which excludes anything that cannot be cast as 'internal' to politics or which sought the legitimation of political power in somehow exclusively political and nonmoral reasons which Erman and Möller dubbed 'hyperautonomy' (see for instance Galston, 2010, p. 387; Sleat, 2010, p. 495, 2014a, pp. 315, 321; Erman and Möller, 2015, p. 227). That this is based on a misreading of Williams has been authoritatively demonstrated, and the term is more appropriately used to draw attention to the realist claim that certain values, principles, or standards can be understood as arising from within the practice of politics itself and/or that the relationship between politics and morality in political theory ought not to be conceived as simply the application of a set of moral principles to political practice (see Hall, 2015).

11 See also Sleat (2013, pp. 63-66; 2014a, p. 315; 2016c, pp. 253-54; 2016b, p. 173; 2016a, p. 68, 2018).

12 See also Hall and Sleat (2017, p. 278), Hall (2020, p. 9).

13 See also McQueen (2020) (first published and available online in 2016).
} 
Most realist work falls into this 'weaker' category. Indeed, we might think of it as the 'mainstream' realist position. ${ }^{14}$ And, as such, we find the literature littered with claims and arguments to the effect that politics must have some (greater) autonomy from morality, whether expressed in terms of autonomy, distinctiveness and/or irreducibility (them not being synonymous with one another) alongside an acknowledgement of the relevance of morality to our normative thinking about politics. That this goes almost totally unacknowledged by those who prefer to cast realists as if they all shared the stronger ambition of a nonmoral political normativity is therefore surprising.

There are, of course, different ways in which the claims and arguments associated with this weaker version of realism can and have been made (compare Philp and Newey above, for instance, both of whom Rossi and myself list, contra Leader Maynard and Worsnip, as advocates of this weaker form of autonomy). But the point for our purposes is simply that however the weaker thesis is expressed and understood, it both represents something like the mainstream realist position and cannot plausibly be interpreted as involved in the endeavour of establishing the grounds for a nonmoral political normativity. We might still want to ask just how distinct political thought needs to be in order to be meaningfully distinctive as political thought if full autonomy is not the aim. But then it is not clear that there is going to be any independent threshold that needs to be met and against which we can assess such distinctiveness, and hence the endeavour looks somewhat misguided and unnecessary. ${ }^{15}$ The more interesting question is whether realists can demonstrate that their approach generates some interesting insights about politics which would be unavailable to us otherwise (a point we shall return to shortly).

\section{The Realist Family}

If we were to tell a genealogy of the debate between realism and its critics there is good reason to suspect it would begin with either a misunderstanding to the effect that realism wanted to develop a nonmoral way of thinking about politics (specifically in relation to legitimacy) or over-emphasising the significance of the remarks of those who did make such claims as representative of realism as a whole. These were then systematised into claims about the sources of moral and political normativity which came to be accepted by advocates and critics as central to the distinction between realism and moralism. Realism thus became the quest for distinctively political normativity; moralism the rejection that nonmoral political normativity is coherent or possible. And as these terms, realism and moralism, were introduced by Williams it surely matters that this was not how he initially cast that distinction.

The contrast that Williams draws between political moralism and political realism turns on how political theory understands the relationship between morality and political practice. In rejecting moralism he says that we reject 'the basic relation of morality to politics as being that represented either by the enactment model or by the structural model' (2005, p. 8-emphasis in the original) in which political theory formulates the principles, concepts, ideals, etc. that we then seek to express through political action (enactment) or sets down the moral conditions of co-existence under power that politics must recognise

14 That Williams' work too falls into this category will be discussed in the following section.
15 A point also made by Jubb (2019, p. 362). 27/09/2021 20:10:00. 
in practice (structural) (2005, p. 1). We should reject this model because it is wrong to view those moral principles or conditions as independent of or prior to political practice. Rather we need to appreciate that they are historical developments whose existence, and our commitment to them, is deeply entwined with the politics that they seek to speak to. The difficulty with moralism is that it fails to recognise how political morality actually is. Or, put differently, what is wrong with political moralism is not that it represents a form of political theory that 'starts' outside of politics, but that it thinks it does. Once we properly recognise the entanglement of politics and morality, we will see that when we come to the question of the foundations of liberalism for instance, that liberal values or principles cannot ground the liberal state because they are, in an important sense, products of the liberal state and the same contingent historical forces that created it $(2005$, p. 8$) .{ }^{16}$ This recognition of the historical contingency of liberal values (as with all values) is potentially deeply destabilising and can undermine our confidence in them. In order to stabilise our confidence in those values Williams suggests that we can turn our attention to the ways in which they address genuine human needs as represented in the 'first political question' (to be free from the terror, torture, cruelty, etc. associated with disorder and instability) and in such a way that makes sense to us as a form of legitimate order, which is to say that it provides an acceptable answer to the basic legitimation demand (BLD), given the universal truth about politics that 'might is not right' (i.e. it can be understood as a solution to that problem and not just the perpetuation of cruelty through force). Assuming this is possible and the basic legitimation demand can be met, and Williams thought it could at least in the case of the liberalism of fear, then we have reason to remain confident in liberal values despite recognition of their historical contingency. ${ }^{17}$

There is an important sense in which the first political question and the BLD are political. They speak to some of the ends that we standardly think politics pursues, the means that it employs, and the issues that these give rise to (that the use of force in the creation of order can become tyrannical). To be sure, Williams thought that we could understand the basic demand that a regime provide a legitimation of its rule in ways that do not presume some particular moral principle or value (e.g. as we are autonomous persons the state needs to demonstrate that its constitutional essentials are such that I could reasonably accept, reject, be expected to accept, etc.), and, in that sense, it does represent an evaluative dimension of politics that we can see as coming from within the practice of politics itself. Is it moral? Williams is ambivalent whether we call it moral or not: 'If it is, it does not represent a morality which is prior to politics' $(2005$, p. 5). What matters is that it does not represent the 'basic relation of morality to politics' that characterises political moralism. He was not at all interested in strongly demarcating between political and moral normativities.

\footnotetext{
${ }^{16}$ Hence it is likely that many realists are going to be deeply sceptical of the ecumenical position advocated by Erman and Möller in their contribution to this special issue that accepts a role for both moral and political values and norms as part of the 'justificatory grounding' of political theories. The problem here will not be the ecumenicism of values (which we have seen realists readily endorse) but that they do not think either moral or political values can provide justificatory grounding for political practices they are the product of.

17 This paragraph draws heavily on the excellent analyses of Williams by Hall and Sagar (Hall, 2014, 2015, 2020; Sagar, 2016; Hall and Sleat, 2017). Of course, all of this can be disputed on its own terms. But that so many critical engagements with Williams focus almost exclusively on 'Realism and Moralism in Political Theory', possibly extended to possibly one or two further essays from In the Beginning was the Deed, as if that is sufficient to understand his thinking on realism is difficult to comprehend given a) he is a thinker renowned for leaving much for the reader to do in piecing together his views from across many different writings; b) Hall, Sagar, Owen (2018), and others have published several authoritative pieces which provide and make clear the necessity of placing Williams' realism in the broader context of his ethical thinking.
} 
In fact, such an ambition seems profoundly at odds with Williams' philosophical approach such that it seems not just strange but incongruous to attribute such an endeavour to him. The term 'normativity' does not appear much in Williams' work. He talks instead in Ethics and the Limits of Philosophy, for instance, of 'considerations' that apply to the Socratic question of 'How should I live?'. He explicitly rejects the thought that we need to decide whether this question is to be given a moral or nonmoral answer, though we can ask 'what should I do from an ethical point of view?', or from an economic perspective, and so on, but "At the end of all that, there is the question "what should I do, all things considered?" There is only one kind of question to be asked about what to do, of which Socrates' is a very general example, and moral considerations are one kind of consideration that bear on answering it' (2011, pp. 6-7). And there is, he thought, no value in defining what counts as a specifically 'ethical' consideration ('It does no harm that the notion is vague'). It is the particular demands of morality, the Peculiar Institution, which requires a sharp demarcation between the moral and nonmoral. Without that demand, however, we can see that there are a range of considerations which fall under the notion of the ethical, and recognise why that range cannot be clearly delimited (2011, pp. 7-8).

For Williams, moralism and realism are differentiated by how they conceive the relationship between morality and political practice. Where moralism assumes a 'basic relationship' between morality and political practice in which the political theorist conceives of themselves as developing the moral principles, values, concepts, etc. that politics is to then either enact or which will structure the limits of politics' rightful exercise of power, realism seeks a more complex account of that relationship and, in doing so, gives appropriate space and weight to that which is distinctive about political practice in our theories. There are, as Hall and myself have pointed out (2017), numerous routes one can take to reach realist conclusions, and clearly not all realists are signed up to Williams' particular account. All share, however, a dissatisfaction with ways in which contemporary political theory conceives of the relationship between political practice and morality, and have critiqued contemporary figures such as G.A. Cohen, David Estlund, Robert Nozick, and John Rawls, as well as raised concerns about the terms of debates or positions such as revisionist just war theory and luck egalitarianism, on these grounds. And all seek a way of doing political theory which is more appropriately sensitive to what is distinctive about politics as a human activity. They differ, naturally, as to precisely what a more realistic theory should look like, the concepts it should use, the questions it should ask, and quite how the normative prescriptions of theory should be filtered through or aligned to the realities of politics. The fact of the matter is that one cannot talk about 'realism' at a level of generality too long before one has to start making distinctions between different 'realisms' ${ }^{18}$ McQueen is surely right that realism is best conceived as a distinctive family of approaches that share the commitments she listed and we quoted in section two: the distinctiveness of politics; disagreement, conflict, and power as ineradicable and constitutive features of politics; rejection of 'utopianism' and 'moralism'; the priority of order. It is distinctive because there are clearly other approaches and positions that reject or do not share these

\footnotetext{
${ }^{18}$ It is telling in that regard that in the several overviews of realist thought that have been published in recent years, including those of a more critical nature, part of what they do is set out competing typologies of realism, between, for instance, strong and weak realisms (Rossi and Sleat, 2014), detachment and displacement (Baderin, 2014), new and old (Nardin, 2017), ordo-, contextual, and radical (Rossi, 2019).
} 
commitments ${ }^{19}$; it is a family because those commitments can be developed and expressed in different ways $(2017$, p. 297). It is understandable that this might make realism a frustratingly 'moving target' for its critics, but the right response to that would be to engage with particular arguments rather than impose a false coherence around a single unifying argument which all realists are supposed to be signed up to. ${ }^{20}$

Thinking about realism as a family helps us also get a better view of the sort of insights that a realist approach to political theorising can generate. Here the proof is clearly in the eating rather than in the recipe, and one cannot do much more than point at particular interventions and invite critics of realism to engage with those and judge for themselves the merits of the approach. To highlight just an illustrative few where the authors have explicitly characterised their arguments as realist or in keeping with realist themes: Samuel Bagg offers an explicitly realist defence of democracy against the recent slew of epistemic challenges by shifting the emphasis away from thinking about competitive elections and universal suffrage as bestowing authority on the demos as the wisest possible sovereign but on to how democracy denies power to various elites and helps resists state capture. The best way of responding to democracy's epistemic critics is to emphasise power over wisdom (2018); Robert Jubb provides a realist defence of non-intrinsic egalitarianism on the grounds that it is compatible with acknowledging the ubiquity of disagreement about values and interests in politics and, furthermore, that such egalitarianism might be a requirement of legitimacy for us 'now and around here' (Jubb, 2015); Alison McQueen defends the motivational power of fear in prompting responses to global climate change (forthcoming); Bernardo Zacka employs an ethnographic approach to provide a richer understanding of the various psychological and institutional pressures faced by 'street-level bureaucrats', the plural considerations they must remain sensitive to, and how these often pull in different directions (2017); And both Andrew Sabl and myself (2013) sketch out very different views of what a more realistic liberalism wouldlook like, the former stating that it would emphasise:

a focus on agents, their decisions, and their strategic contexts or situations; a sense of the pervasive and permanent relevance of interests, conflicts and power to politics and to political theory; respect for instrumental rationality and comfort with hypothetical imperatives; a love of ugly facts and political complexity; an awareness that a crucial part of being powerless is standing especially in need of institutional - rather than philosophical - restraints on power; and an insistence that, given that no set of political reasons will seem 'legitimate' to everyone, state action rests partly on the authority of institutions rather than the persuasiveness of arguments, and citizen politics uses pressure [sic] (strikes, boycotts, shaming and ostracism) as well as reasons $\left(2017\right.$, p. 349). ${ }^{21}$

19 Another familiar critique of realism denies its distinctiveness: its central commitments are so vague or general that there seem to be few theorists who would not qualify as realists. If that were true then it would be quite peculiar that realism has found itself the subject of much substantive critique, some of it based on fair or judicious readings of realist arguments. Moreover, and as mentioned earlier, realists have undertaken much work to demonstrate their distinctiveness through critical engagement with central figures in contemporary political theory.

20 For a discussion along the same lines see Hall, 2020, pp. 170-74.

21 Other examples would include Philp on corruption (2018) and care for the aged (2016), Bell on poverty (2018), Newey on toleration (2013), Bull on mercy (2019), Hall on political integrity (2018), Bellamy on constitutionalism (2007) and democratic leadership (2018), Galston on the 'darker passions' (2018), and Sagar on how economic reality has to constrain theoretical accounts of freedom (2019). 
There is also plenty of work being done by those who have not (and maybe might not) align themselves with realism but which nevertheless represents good examples of the sort of themes or approaches that realists have been endorsing. They might not call themselves 'realists' but we can see that they might still bear some familiarly realist family resemblances. These would include, for instance, Teresa Bejan's defence of 'mere' civility as a vital virtue in helping us live together in conditions of permanent difference and disagreement (2017); Jeremy Waldron's insistence on the importance of the study of institutions as ways in which we house, frame, and manage our disagreements about social ideals and orchestrate what is to done about whatever aims we can agree upon (2016), and; Jacob T. Levy's arguments against ideal theory (2016) and prevailing forms of teleological thinking in contemporary political theories $(2020){ }^{22}$

Of course, realists may not have succeeded in showing that we should reject the prevailing accounts of the relationship between morality and politics which it finds so problematic in contemporary political theory. Nor might it have a compelling account of how political theory should go on in a more realistic key. But it matters what realists' arguments are and are not being put in the service of. In this regard the debate about a distinctive nonmoral political normativity has been an unfortunate and unnecessary distraction.

Open Access This article is licensed under a Creative Commons Attribution 4.0 International License, which permits use, sharing, adaptation, distribution and reproduction in any medium or format, as long as you give appropriate credit to the original author(s) and the source, provide a link to the Creative Commons licence, and indicate if changes were made. The images or other third party material in this article are included in the article's Creative Commons licence, unless indicated otherwise in a credit line to the material. If material is not included in the article's Creative Commons licence and your intended use is not permitted by statutory regulation or exceeds the permitted use, you will need to obtain permission directly from the copyright holder. To view a copy of this licence, visit http://creativecommons.org/licenses/by/4.0/.

\section{References}

Baderin A (2014) Two forms of realism in political theory. Eur J Polit Theory 13(2):132-153

Bagg S (2018) 'The power of the multitude: answering epistemic challenges to democracy. Am Polit Sci Rev 112(4):891-904

Bejan T (2017) Mere civility: disagreement and the limits of toleration. Harvard University Press, New York

Bell D (2018) Security and poverty: on realism and global justice. In: Sleat M (ed) Politics recovered: realist thought in theory and practice. Columbia University Press, New York, pp 296-319

Bellamy R (2007) Political constitutionalism: a republican defence of the constitutionality of democracy. Cambridge University Press, Cambridge

Bellamy R (2018) The paradox of the democratic prince: Machiavelli and the neo-Machiavellians on ideal theory, realism, and democratic leadership. In: Sleat M (ed) Columbia University Press, New York. pp 166-93

Bull M (2019) On mercy. Princeton University Press, Oxford

Erman E, Möller N (2015) Political legitimacy in the real normative world: the priority of morality and the autonomy of the political. Br J Polit Sci 45(1):215-233

Erman E, Möller N (Forthcoming) Distinctively political normativity in political realism: unattractive or redundant. Ethical Theory Moral Pract

Estlund D (2017) Methodological moralism in political philosophy. Crit Rev Int Soc Polit Philos 20(3):385-402

\footnotetext{
22 We could also include in this list Bernard Yack's work on nationalism (2012), Rahul Sagar on secrecy and whistleblowing (2014), Mark Pennington on 'robust political economy' (2011), and John McCormick's 'Machiavellian Democracy' (2011).
} 
Galston W (2010) Realism in political theory. Eur J Polit Theory 9(4):385-411

Galston W (2018) Anger, humiliation, and political theory: bringing the darker passions back in. In: Sleat M (ed) Columbia University Press, New York. pp. 93-113

Geuss R (2008) Philosophy and real politics. Princeton University Press, Oxford

Geuss R (2014) A world without why. Princeton University Press, Oxford

Hall E (2014) Contingency, confidence, and liberalism in the political thought of Bernard Williams. Soc Theory Pract 40(4):545-569

Hall E (2015) Bernard Williams and the basic legitimation demand: a defence. Polit Stud 63:466-480

Hall E (2017) How to do realistic political theory (and why you might want to). Eur J Polit Theory 16(3):283-303

Hall E (2018) Integrity in democratic politics. Br J Polit Int Relat 20(2):395-408

Hall E (2020) Value, conflict, and order: Berlin, Hampshire, Williams and the realist revival in political theory. University of Chicago Press, Chicago

Hall E, Sleat M (2017) Ethics, morality and the case for realist political theory. Crit Rev Int Soc Polit Philos 20(3):278-295

Jubb R (2015) The real value of equality. J Polit 77(3):679-691

Jubb R (2019) On what a distinctively political normativity is. Polit Stud Rev 17(4):360-369

Jubb R, Rossi E (2015) Political norms and moral values. J Philos Res 40:455-458

Leader Maynard J, Worsnip A (2018) Is there a distinctively political normativity? Ethics 128:756-787

Levy JT (2016) There is no such thing as ideal theory. Soc Philos Policy 33(1/2):334-353

Levy JT (2020) Contra politanism. Eur J Polit Theo 19(2):162-183

McCormick JP (2011) Machiavellian democracy. Cambridge University Press, Cambridge

McQueen A (2017) Political realism and the realist "Tradition." Crit Rev Int Soc Polit Philos 20(3):296-313

McQueen A (2018) The case for kinship - classical realism and political realism. Politics recovered: realist thought in theory and practice. Columbia University Press, New York, pp 243-269

McQueen A (2020) Political realism and moral corruption. Eur J Polit Theory 19(2):141-161

McQueen A (2021) The wages of fear? Toward fearing well about climate change. Philosophy and climate change. Oxford University Press, Oxford

Miller D (2016) In what sense must political philosophy be political? Soc Philos Policy 33(1-2):155-174

Nardin T (2017) The new realism and the old. Crit Rev Int Soc Pol Philos 20(3):306-319

Newey G (2001) After politics: the rejection of politics in contemporary liberal philosophy. Palgrave, Basingstoke

Newey G (2010) Two dogmas of liberalism. Eur J Polit Theo 9(4):449-465

Newey G (2013) Toleration in political conflict. Cambridge University Press, Cambridge

Owen D (2018) Realism in ethics and politics: Bernard Williams, political theory, and the critique of morality. Politics recovered: realist thought in theory and practice. Columbia University Press, New York, pp 73-92

Pennington M (2011) Robust political economy: Classical liberalism and the future of public Policy. Edward Elgar, Cheltenham

Philp M (2007) Political conduct. Harvard University Press, New York

Philp M (2010) What is to be done? Political theory and political realism. Eur J Polit Theo 9(4):466-484

Philp M (2016) Justice, realism, and family care for the aged. Soc Philos Policy 33(1/2):413-433

Philp M (2018) Politics and the "Pure of Heart" realism and corruption. In: Sleat M (ed) Politics recovered: realist thought in theory and practice. Columbia University Press, New York, pp 194-217

Prinz J (2016) Raymond Geuss' radicalization of realism in political theory. Philosophy \& Social Criticism 42(8):777-796

Prinz J, Rossi E (2017) Political realism as ideology critique. Critical Review of International and Social Political Philosophy 20(3):334-348

Raekstad P (2018) Realism, utopianism, and radical values. Eur J Philos 26(1):145-168

Rossi E (2019) Being realistic and demanding the impossible. Constellations 26:638-652

Rossi E, Sleat M (2014) Realism in normative political theory. Philos Compass 9(10):689-701

Sabl A (2017) Realist liberalism: an agenda. Crit Rev Int Soc Pol Phil 20(3):349-364

Sagar P (2016) From scepticism to liberalism? Bernard Williams, the Foundations of Liberalism and Political Realism. Political Studies 64(2):368-384

Sagar P (2019) Liberty, nondomination, markets. Review of Politics 81(3):409-434

Sagar R (2014) Secrets and leaks: the dilemma of state secrecy. Princeton University Press, Oxfordshire

Sleat M (2010) Bernard Williams and the possibility of a realist political theory. Eur J Polit Theo 9(4):485-503

Sleat M (2013) Liberal realism: a realist theory of liberal politics. Manchester University Press, Manchester 
Sleat M (2014a) Legitimacy in realist thought: between moralism and "Realpolitik." Political Theory 42(3):314-337

Sleat M (2014b) Realism, liberalism and non-ideal theory or, are there two ways to do realistic political theory? Political Studies 64(1):27-41

Sleat M (2016a) The politics and morality of the responsibility to protect: beyond the realist/liberal impasse. International Politics 53(1):67-82

Sleat M (2016b) The value of global justice: realism and moralism. Journal of International Political Theory 12(2):169-184

Sleat M (2016c) What is a political value? Political philosophy and fidelity to reality. Soc Philos Policy 33(1-2):252-272

Sleat M (2018) Politics recovered - on the revival of realism in contemporary political theory. In: Sleat M (ed) Politics recovered - realist thought in theory and practice. Columbia University Press, New York, pp 1-25

Waldron J (2016) Political political theory. Harvard University Press, New York

Williams B (2005) In the beginning was the deed: realism and moralism in political argument. Princeton University Press, Oxford

Williams B (2011) Ethics and the limits of philosophy. Routledge, London

Yack B (2012) Nationalism and the moral psychology of community. University of Chicago Press, Chicago

Zacka B (2017) When the state meets the street: public service and moral agency. Belknap Press, London

Publisher's Note Springer Nature remains neutral with regard to jurisdictional claims in published maps and institutional affiliations. 